\title{
CURRENT APPROACHES TO PUBLIC ADMINISTRATION EMPLOYEE EVALUATION
}

\author{
INETA LAKSTIGALA \\ SIGNE BALINA
}

\begin{abstract}
Human work is increasingly replaced by the new technologies, while the operations are divided and subverted so that there is no way to get along without human resources. Therefore, institutions are unable to dispense with the knowledge and skills of the employees in order to move together and to achieve the objectives pursued. Public administration, as an institution, has its own objectives and tasks, which any employed person needs to be clearly aware of and to understand the importance of their job. Therefore, each official and employee of public administration has their job description, while performance and quality of the work commitments shall depend on the knowledge, skills, personality and competence of the employees themselves. Therefore, the assessment of employees is carried out every year in public administrations, according to certain criteria, for the purpose to measure the quality of work and the compliance of employees in a given position. In the course of the evaluation process competencies, knowledge, professionalism, cooperation and quality of work of the employees are assessed. The purpose of the research is to consider and to clarify the methods of assessment of the employees and the way in which the process of evaluation of employees is taking place. The main questions are: whether consultations are carried out after evaluation and what is the impact of its result on the employee. What skills and competences are required for the public administration employees. The methods used by the research are literature analysis, document analysis and direct observations. The research results will be applied in practice by means of improving the process of evaluation of public administration employees. According to the data obtained, it will be possible to identify what are the affecting factors in the process of evaluation.
\end{abstract}

Key words: Latvia, competence, evaluation, knowledge

JEL code: M59, M12, D89

\section{INTRODUCTION}

Today, the knowledge and competence of employees is of great importance since the competencies, knowledge, performance of job assignments and responsibilities of the employees are assessed in accordance with the performance criteria for those employed by the public administration. The evaluation process assesses compliance of the employee with a particular position and the need to improve any knowledge, qualifications, or skills. Therefore, subjective assessment should be avoided in the performance evaluation process. A major role in the 
evaluation process is played by communication and interaction, for the manager to discuss the procedure and outcome of the evaluation process with their subordinate.

The evaluation process results in a potential assessment of the achievements of the institution's staff, the problems that appeared through the work and the factors affecting it, leading to a possible objective set in order to improve the performance, development of qualifications, professional knowledge and competencies of the employees.

\section{EVALUATION OF THE PERFORMANCE}

Evaluation of the performance of those employed with an institution is playing a practical role for determination of their office remuneration, career opportunities, dismissal, ensuring motivation of the employees and the possibility for assessing the skills, performance, knowledge and training requirements of the employees. In the process of evaluation of performance, it is clarified how people should be reached and managed in order to attain the desired outcome (Armstrong, 2004). In order to continuously develop there must be five abilities:

- ability to create and disseminate a single vision,

- ability to share knowledge and to learn in a team,

- ability to develop proficiency by motivating the organisation staff, constantly searching and acquiring additional knowledge,

- ability to identify, to evaluate and to change the way of thinking of members of the organisation, and

- ability to apply systems approach by means of distinguishing processes as a systematic and a cyclical interconnected network rather than a linear chain of events (Senge, 1997).

The evaluation process focuses on the incidence of errors, failures, quality, organisational skills, interpersonal and communication skills.

One of the objectives of the performance evaluation shall be to assess the performance according to the evaluation criteria (the work result, competencies, motivation, satisfaction, ensuring feedback, planning of training and development); to identify what knowledge and skills must be improved. "The choice of an evaluation method shall be determined by the purpose of evaluation. Depending on the purpose, the employee's competency, performance, the work result or the employee's behaviour shall be assessed. The evaluation process can be considerably facilitated by developing and implementing evaluation criteria and a list of competencies. In turn, it is possible for each criterion to define and to describe the assessment levels by means of scoring, percentage systems or verbal descriptions, evaluation of specific requirements, standard behaviour characterization" (Dombrovska, 2009, 77). The evaluation should be considered to be an opportunity for growth, reflecting the works performed and 
achievements made in determining whether the set target and objectives have been achieved. "Competency approach in this time, which is full of challenges, offers a human resource management method widely used in selection, career planning, performance assessment and staff development" (Spencer, Spencer, 1993). In the evaluation processthe same principles are followed (Armstrong, 2007), the manager shall assess:

- how are the objectives, job responsibilities and tasks fulfilled;

- quality, deadlines for implementation of the work results;

- competencies, behaviour, actions, knowledge;

- amount of work, workload;

- working conditions (problems, nuisance factors);

- level of satisfaction of the employees; and

- career planning.

"The objective of managers in the evaluation process shall be: to establish a reciprocal, free dialogue, to understand the employee and to be understood, to provide support to the employee, to carry out an overview of the results attained and unattained, by means of evaluation of the incentive factors, to identify the performance obstacles, to identify the potential and to evaluate the competency of the employee, to set new work targets and to evaluate the work performed" (Ešenvalde, 2008, 135). In a given period of time, it is possible to assess the contribution of the employee, the quality of their work, the problems encountered in the work process. Therefore, the purpose of evaluation of the performance shall be to create the desire for employees to improve and to enhance their work (Latham, Wexley, 1977).

Performance of the job responsibilities may be not always depending upon the employee in charge, due to the fact that the colleagues, the customers and the manager may affect it. Therefore, the evaluation process is a "sensitive" process and, when assessing the performance, there is a possibility for subjective assessment. The evaluation respects equivalent principles of evaluation, the employee learns what is falling within their competence, while one can watch the way it happens (Armstrong, 2004). The evaluation process makes it possible to determine whether the objective pursued has been achieved, and what work is contributed, whether the institutions take care of professional growth and development of their employees, participate in the improvement of communication and interaction, regulate pay changes and reduce staff turnover.

\section{PERFORMANCE EVALUATION SYSTEM IN PUBLIC ADMINISTRATION}

In the public administration are using the Performance Evaluation System the Information System of the Electronic Evaluation Form (hereinafter referred to as the NEVIS). But before the introduction of NEVIS, forms were used to 
evaluate the performance of work, which could be filled in both handwritten and computerized, but the forms were signed on paper and stored in paper. Therefore, one of the goals of NEVIS implementation is to reduce the volume of documents. The evaluation system is focused on knowledge and skills whilst less on competencies.

Knowledge, as well as the competencies, are of great importance today (Alvesson, 2004). Each year (at the beginning of the year), the objectives of the institution shall be set, where in accordance with the structure of the institution, the intended performance tasks shall be set. The objective of evaluation of the performance shall ensure consistency between the institution, entity objectives, values and behaviours, by ensuring fairness and transparency evaluation and building a framework for linking between performance assessment and remuneration, growth of employees and ensuring communication (Armstrong, 2006).

The evaluation system involves a number of problems (Latham \& Latham, 2000). Due to the fact that the employees' knowledge, abilities and skills are not linked to the assessment, the evaluation process, a possibility to encounter a formal employee evaluation or self-assessment - in a short and concise manner: a reply written for form only or "to versify". In the evaluation process, it is important to assess the performance of subordinates, the need for training, the opportunities for growth, and, if necessary, by attracting specialists. It is important that evaluation of the performance should take place in the light of the principle of honesty and equality. When assessing an employee, it is always necessary to build on the previous assessment in order to define more precisely the changes in the performance, knowledge and competency (Covey, 2013).

In the evaluation process, it is important to avoid criticizing an employee, but to see the positive aspects, to say good things, and to recommend improving and developing shortcomings. The manager needs to find out what is an obstacle and problems that interfere with performance of the job assignments in good quality in order to help an employee within the limits of opportunity. In order to say good words, every manager themselves have to work with it, observe good things and be able to assess the accomplishments, because it is possible to achieve better productivity with positive attitude. Mutual understanding and properly used communication should therefore play a highly important role for the employee to feel necessary and to be assessed appropriately. The manager must be open for communication with any employee, regardless of human character and temperament.

Highly qualified, competent and motivated staff is one of the most important conditions for the promotion of labour productivity. In order to promote this, the importance of evaluation of the performance is increasing; the right approach should be found to collaborate, to motivate employees, to develop a fair remuneration system, taking care of development, results and effectiveness of one's work (Raudeliūiene, Meidute-Kavaliauskiene, 2014). 


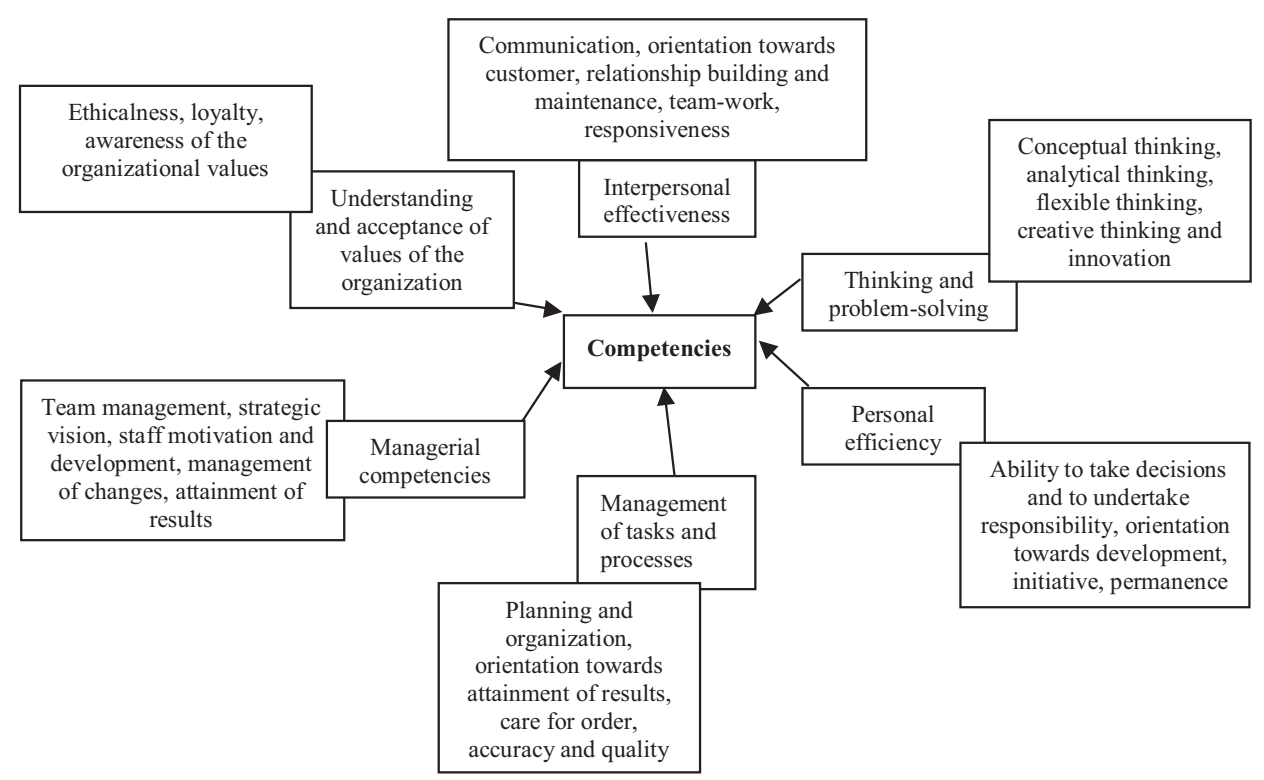

Source: created by authors, based on Kompetenču värdnīca, 2011

Fig. 1. Competencies of the performance evaluation

Training, level of professional experience, levels of professional knowledge and skills, general knowledge shall be assessed for professional qualifications of the employees. However, assessment of competence of the employees shall be based (Kompetenču vārdnīca, 2011) on six levels of the Competency Dictionary (see Figure 1), according to which the employee is evaluated by analysis of competency, knowledge and skills of the employee

The performance of official responsibilities shall be assessed based on the performance of official responsibilities as defined in the job description quality performance standards. Indeed, the objectives for implementation of the system are realistic and facilitate the job, effectiveness of its application and how positive are its results, is falling within the responsibility of each user. There are risks inherent in the course of any process. This applies also to evaluation of the employees. They may have a formal approach, with short and concise assessment, while placing emphasis on assessment, as well as an opportunity exists for a disproportionately high or low assessment. The evaluation process is valuable if it is approached with a sense of responsibility and a significantly greater time is devoted.

\section{EVALUATION PROCESS FOR EMPLOYEES}

The evaluation process NEVIS starts when the manager, at the beginning of the year, is nominating an overriding goal to be achieved during a certain time period (usually during one year). As a result, each employee is setting specific tasks 
that are planned to be accomplished during the year. The process of evaluating the work consists of the following stages:

1. Planning of work execution - determination of the goals to be achieved and tasks to be performed, agreement on the requirements for the fulfillment of the official duties;

2. Updating the performance of the work, at least once a year, reviews the performance of the work according to the requirements set for the post, the goals and tasks set and the status of execution;

3. Performance appraisal by performing performance analysis and evaluating the results and investment criteria;

4. Job Execution Assessment Negotiations, which take place when meeting the manager with the employee (New Assessment System for Public Administration Employees, 2012).

Less than a year later, each employee individually performs self-assessment of the accomplishments, knowledge, problems and competencies. All this shall be maintained and confirmed for the purpose that the direct manager can assess each employee individually. The direct manager shall evaluate the employee by filling out all the necessary fields in the system by placing an appropriate rating. Individual negotiations shall be carried out before or after approval of the assessment. The conduct of negotiations is optional because it takes a lot of time to negotiate the evaluation process and the job contribution with each employee individually. The employees shall have the right to express dissatisfaction concerning the evaluation process, and the process of re-evaluating options, to conduct and to negotiate with members of the commission in order to resolve uncertain problems in the evaluation process. The attitude of employees towards the evaluation process tends to be negative because it is perceived as a burden. While employees are awarded cash bonuses after evaluation, it is easy for the manager to determine which employee is appropriate and which one is less inappropriate for the official position resulting from the evaluation process. However, the greatest shortcoming in the evaluation process is how objectively self-assessment and assessment of subordinates is performed. There is always a risk of disagreement, frustration and conflict as a result of subjective evaluation. Therefore, it is important that consultations be carried out after evaluation of the employees. According to information at the disposal of the HR management of the institutions, only about $25-30 \%$ of direct managers are negotiating the evaluation process. Both managers and subordinates are the initiators of negotiations. This is a relatively low indicator, given that the ministries work about 3300 thousand people (the public administration needs to change-the lower number of employees still does not improve the efficiency). Given that the managers do not organise individual negotiations with each employee, there may be several reasons: indifference, irresponsible attitude, reluctance, fear of discussing the evaluation process, workload. Electronic environmental features alienate people from interpersonal contacts and communication; therefore, it is 
important for the manager not to forget direct contacts and communication with the employees by improving labour relations and mutual trust.

The system is not remotely distanced from interpersonal communication and communication, but the assessment process creates stress, because the system is used at least twice a year, and people are experiencing problems in mastering the system. It also raises the problem of changing the password, rarely accepting a password, after the first entry. The easier the password, the more likely it will be when you accept it. As well as the self-assessment and evaluation process, there are limits to the number of words that restrict the text. As another negative feature can be mentioned, changes or additions made to the system should be kept on a regular basis if this is not done, the system will unload the user and everything must start with the new one. But in spite of these shortcomings, the employee can perform an assessment of the performance at any time, and the possibility of a third person having access to the evaluation results has diminished.

In order to clarify the process of evaluating the public administration employees, monitoring was carried out in the institutions "public administration 1 " and "public administration 2", through monitoring the process of evaluating employees using the NEVIS advantages and disadvantages. The evaluation process accords great importance to education and qualification of the employees and its regular development. In 2017 "public administration 1" employs 3\% staff with $\mathrm{PhD}$ degrees, while "public administration 2 " - 2\%, while in the "public administration 1" higher education has been obtained by $89 \%$ and in the "public administration 2" - 98\%. While in the "public administration 1", $8 \%$ of employees have secondary vocational education or general secondary education (see Table 1).

Table 1

Education acquired by the employees

\begin{tabular}{|c|c|c|c|}
\hline Institutions & PhD & $\begin{array}{c}\text { Higher Education (Bachelor } \\
\text { and Master Degrees) }\end{array}$ & $\begin{array}{c}\text { Secondary vocational } \\
\text { education }\end{array}$ \\
\hline “public administration 1" & $3 \%$ & $89 \%$ & $8 \%$ \\
\hline "public administration 2" & $2 \%$ & $98 \%$ & - \\
\hline
\end{tabular}

Source: created by authors

In order to ensure successful compliance with the assignments, in 2016, the institution's employees participated in the qualification and the professional knowledge improvement activities (courses, seminars, etc.), such as the institution "public administration 1" has attended education establishments around 207 times, while in the institution "public administration 2" - 454 times. In the light of the School of Public Administration (hereinafter referred to as SPA) data in 2016, the number of training services has increased (see Figure 2) since 2009. Taking into account the fact that from 2008-2010 Latvia was hit by the financial crisis, the budget was not invested in education of employees. Therefore, 
from 2008 to 2009, the study visit has slowed down, which has been gradually increasing since 2009. Increasingly, there is a growing emphasis on educating and improving the skills of employees in order to have skilled and knowledgeable specialists working in the public administration.

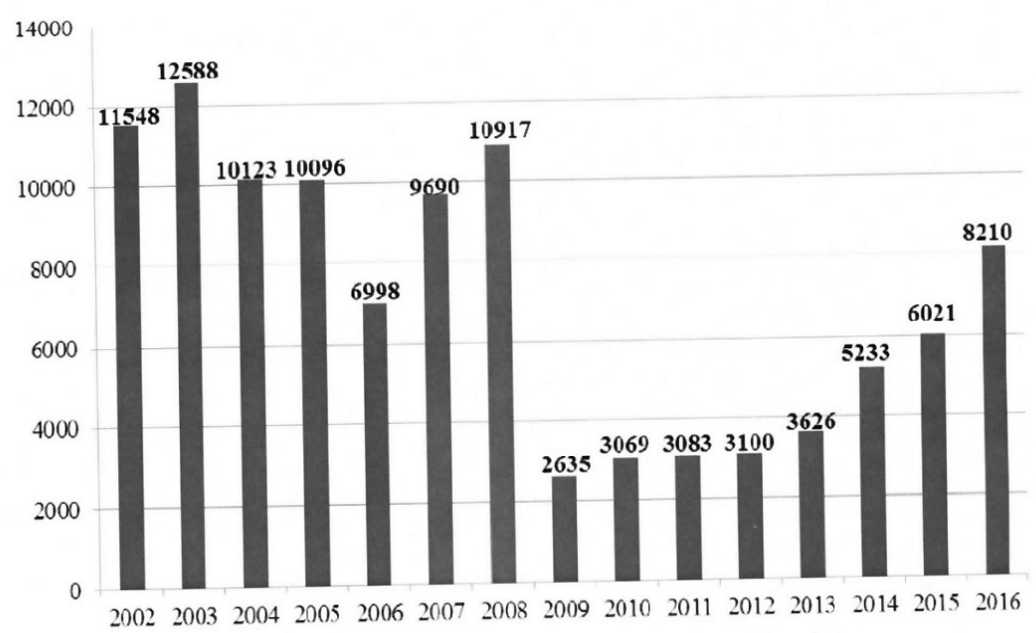

Source: Valsts Administrācijas skola, 2016

Fig. 2. Number of participants of basic studies at SPA

SPA offers public administration courses and seminars to all those employed by public administration through identification of training needs, after evaluating the performance on an individual basis. There is a comprehensive selection of courses and seminars - around 157 training courses according to expectations and requirements. In the training process, it is important that the employee obtain useful knowledge and are able to apply the same during the work process. It is important that people would be focused on self-development and willingness to improve, by achieving a better performance. Motivated and satisfied employees are more interested in self-development because they are motivated to work qualitatively with a desire to attain their targets. Whilst, unmotivated people are more passive, hence there is a chance that a few of them are indifferent towards the development of knowledge. Attendance of training institutions is more as a responsibility of each employee, particularly if compulsory training is not attended, which is organised within the framework of the institution. The manager should take an interest whether employees are attending both recommended and compulsory training, after which it is possible to determine whether an employee is interested in working and developing additional knowledge, skills and competencies according to their position. It is very important that the knowledge acquired in the learning process is applied practically and that the training received 
is of substantial content, interesting and up-to-date. The knowledge acquired in the process of evaluating the work and its usefulness can not be estimated only by the fact that the employee has received the certificate. A worker can obtain several certificates a year, but if the acquired knowledge and competences can not be applied in practice, then the results of the work will not improve. And it can be concluded that the performance of a job depends more on the employee's own responsibility and the desire to improve his skills and competences. But the manager must be motivated to learn from. As a result, performance measurement is a complex process based on subjective opinion and formal discovery. Therefore, those responsible for the human resources of the public administration must explain the purpose, purpose and purpose of the assessment system and the functions and possibilities of using the system. Managers and employees have to change the attitude to the evaluation process without perceiving evaluation as a formal process. Employees need to create an understanding of the functioning of the evaluation system in order for the employee to be able to use the system, why it is necessary to make an assessment and professional development results. As well, the manager should ensure a feedback by maintaining communication and building mutual trust. In principle, public administrations should keep track of the education they receive from their staff, so that high-level positions are taken up by educated and knowledgeable professionals. The purpose of using the performance measurement system is considered incomplete in order to be in line with the goal set for effective use of human resources in public administration, it is necessary to eliminate all identified factors and attitudes from the manager and employees.

\section{CONCLUSIONS, PROPOSALS, RECOMMENDATIONS}

Based on the analysis of the literature and the research carried out, the authors conclude:

1. The evaluation process allows for the assessment of staff achievements and errors occurred in the work process, determination whether the objective pursued has been achieved and what work is contributed in taking care of the professional growth and development of the institution's employees, improvement of mutual communication and contacts, adjusting remuneration changes, providing training for the employees, and by reducing staff turnover as far as possible.

2. In the evaluation process, it is important to assess performance, training needs, and growth opportunities of the subordinates during a certain time period, by involving specialists, if necessary.

3. The need for attending courses for the employees shall be determined after assessment, by evaluating what competences need to be improved. Therefore, negotiations have an important role to play in the evaluation process where it is possible to suggest what competencies need to be improved. Negotiations 
should be aimed at improving motivation and satisfaction, understanding, mutual collaboration, understanding of employees of the institutional goals, and their role in achieving it by improving the performance process.

The following proposals have been suggested in course of the work:

1. The managers and the HR management of the institutions should follow the training and attendance thereof the employees, setting out a compulsory attendance of training related to the official position, and to motivate the learning of new knowledge in order to improve the quality of work.

2. Each year, the HR management of the institution must verify statistically the attendance of training of the employees and in course of the evaluation process has to evaluate the benefits of training and the performance through evaluation of the benefits of training.

\section{REFERENCES}

Alvesson, M. (2004a). Knowledge Work and Knowledge - Intensive Firms. Oxford: Oxford university press, pp. 271.

Armstrong, M. (2004b). How to be an even better manager. A complete A-Z of proven techniques \& essential skills. Kogan Page, pp. 299.

Armstrong, M. (2007). Hanbook of Employee Reward Management and Practice. London; Philadelphia: Kogan Page, pp. 491.

Armstrong, M. (2009). Armstrong's Handbook, of Human Resource Management Practice (11th Edition). Kogan Page, London and Philadelphia, pp. 1063.

Kompetenču vārdnīca (2011). Retrieved from: https://www.mk.gov.lv/sites/default/ files/editor/kompetencu_vardnica.pdf_1.pdf.

Covey, S. R. (2013). The 7 habits of highly effective people: powerful lessons in personal change. 25th anniversary edition / with a foreword by Jim Collins. New York: Simon \& Schuster, pp. 391.

Dombrovska, L. R. (2009). Cilvēkresursu kapitāla vadība. Rìga: Zvaigzne ABC, p. 212.

Ešenvalde, I. (2008). Personāla vadības mūsdienu metodes. Rīga: Merkūrijs LAT, p. 349.

Jauna novērtēšanas sistēma valsts pārvaldē strādājošajiem, (2012). Retrieved from: https://lvportals.lv/skaidrojumi/250038-jauna-novertesanas-sistema-valstsparvalde-stradajosajiem-2012.

Latham, G. P., Wexley, K. N. (1977). Behavioral observation scales for performance appraisal purposes. Personnel Psychology, 30, 255-268.

Valsts Administrācijas skola, (2016, 2015). Retrieved from: http://www.vas.gov.lv/lv/ jaunumi?\&start $=1$.

Senge, P. M. (1997). The Fifth Discipline. Great Britain: century Business, pp. 424.

Spencer, L. M., Spencer, S. M. (1993). Competence at work: models for superior performance. Wiley, pp. 372.

Valsts pārvaldei jāmainās - mazāks darbinieku skaits efektivitāti vēl necels (2017). Retrieved from: https://lvportals.lv/viedokli/292216-valsts-parvaldei-jamainasmazaks-darbinieku-skaits-efektivitati-vel-necels-2017.

Raudeliūiene, J., Meidute-Kavaliauskiene, I. (2014). Analysis of factors motivating human resources in public sector. ScienceDirect, pp. 720. 